\title{
New developments in C5a receptor signaling
}

This article was published in the following Dove Press journal:

Cell Health and Cytoskeleton

30 July 2012

Number of times this article has been viewed

\section{J Vidya Sarma}

Peter A Ward

University of Michigan Medical School, Department of Pathology, Ann Arbor, MI, USA
Correspondence: Peter A Ward;

J Vidya Sarma

University of Michigan Medical School,

Department of Pathology,

I30| Catherine Rd, Box 5602,

Ann Arbor, MI 48I09-5602, USA

Tel + I 734647292 I

Fax +I 7347644308

Email pward@umich.edu;

vsarma@umich.edu
Abstract: Complement activation usually results in the formation of complement fragment $5 \mathrm{a}(\mathrm{C} 5 \mathrm{a})$ that interacts with its two receptors, C5aR and C5L2. These receptors belong to the rhodopsin family of $\mathrm{G}$ protein-coupled seven transmembrane-containing receptors. $\mathrm{C} 5 \mathrm{aR}$ and C5L2 are expressed on/in a wide variety of cells and tissues. Interaction of C5a with C5aR leads to many pleiotropic effects, including the release of cytokines and chemokines and recruitment of inflammatory cells. In certain circumstances, C5a-C5aR interactions can also result in pathophysiological changes as seen in sepsis, rheumatoid arthritis, asthma, acute lung injury and ischemia-reperfusion injury. This overview of the $\mathrm{C} 5 \mathrm{a}-\mathrm{C} 5 \mathrm{aR}$ interactions describes how such interactions facilitate the pivotal role the complement system plays in the host's innate and adaptive responses.

Keywords: receptors, signal transduction, inflammation, immune response

\section{Introduction}

The complement system evolved a long time ago - perhaps as long as 700 million years ago - before the appearance of immunoglobulins. ${ }^{1}$ The complement system optimizes clearance of antigen-antibody complexes in plasma, opsonization of invading pathogens followed by phagocytosis, cell lysis, and promotion of inflammation, in many instances resulting in recruitment of inflammatory cells. Inadequately controlled complement activation can cause inflammatory disorders such as asthma, ${ }^{2}$ atherosclerosis, ${ }^{3}$ glomerulonephritis, ${ }^{4}$ and sepsis. ${ }^{5}$

\section{Complement activation pathways}

The complement system consists of numerous proteins that are present in either soluble form (mostly in the plasma) or in bound form at local inflammatory sites and in cell membranes. The soluble proteins normally exist in an inactive form that can be rapidly activated and amplified by a series of sequentially acting proteases that are tightly regulated. Complement activation ultimately leads to the formation of the anaphylatoxins C3a, C4a, and C5a (reviewed in Sarma and Ward ${ }^{6}$ ). Of these, C5a is one of the most phlogistic peptides involved in diverse immune and non-immune responses.

The classical pathway (reviewed in Sarma and Ward ${ }^{6}$ ) is activated when immunoglobulin (Ig) G or IgM antibodies bind to bacteria, apoptotic cells, and other antigens, resulting in the multimeric $\mathrm{C} 1$ complex (consisting of $\mathrm{C} 1 \mathrm{q}, \mathrm{C} 1 \mathrm{r}$, and $\mathrm{C} 1 \mathrm{~s}$ ) binding to the Fc portion of $\mathrm{IgG}$ or IgM, followed by sequential cleavage of $\mathrm{C} 4$ and 
$\mathrm{C} 2$ to form the C3 convertase C4b C2a (Figure 1). The lectin pathway (reviewed in Sarma and Ward ${ }^{6}$ ) is activated when mannose-binding lectin - which consists of large oligomers assembled from identical polypeptides and ficolins (proteins with an amino-terminal collagen-like domain and a carboxyl-terminal globular fibrinogen-like domain) recognizes carbohydrate groups on cell surfaces of pathogens and activates the mannose-binding lectin-associated serine proteases. In turn, these cleave $\mathrm{C} 4$ and $\mathrm{C} 2$ to form the $\mathrm{C} 3$ convertase $\mathrm{C} 4 \mathrm{~b} \mathrm{C} 2 \mathrm{a}$. The alternative pathway (reviewed in Sarma and $\mathrm{Ward}^{6}$ ) is activated when C3b (formed as a result of the constant low-level hydrolysis of $\mathrm{C} 3$ ) recognizes lipopolysaccharide (LPS) on the surfaces of bacteria and other pathogens followed by the recruitment of factors $\mathrm{B}$ and $\mathrm{D}$ to the bound $\mathrm{C} 3 \mathrm{~b}$ and formation of the $\mathrm{C} 3$ convertase $\mathrm{C} 3 \mathrm{bBb}$. $\mathrm{C} 3$ convertases cleave to $\mathrm{C} 3$ and form the $\mathrm{C} 5$ convertases that then cleave $\mathrm{C} 5$ to form $\mathrm{C} 5 \mathrm{a}$ and $\mathrm{C} 5 \mathrm{~b} .{ }^{6}$ Various studies have suggested that activated neutral proteases can also cleave C5, especially during inflammatory conditions. This activation is referred to as the "extrinsic pathway" of the complement system. For example, thrombin, a coagulation pathway protein, can generate $\mathrm{C} 5$ a locally in vivo in the absence of the conventional $\mathrm{C} 5$ convertase in $\mathrm{C} 3$-deficient mice. ${ }^{7}$ Further, proteases released by neutrophils and macrophages can also generate complement activation products. ${ }^{8,9}$

\section{C5a}

Human C5a (approximately $15 \mathrm{kDa}$ ) is glycosylated and consists of 74 amino acids (aa). Nuclear magnetic resonance studies indicate that it is a globular protein consisting of helices stabilized by disulfide bridges in the core and a flexible C-terminal tail (64-74 aa). ${ }^{10} \mathrm{C} 5$ is a $190 \mathrm{kDa}$ protein consisting of an alpha chain $(\sim 120 \mathrm{kDa})$ and a beta chain $(\sim 75 \mathrm{kDa})$ connected by disulfide bonds. ${ }^{11} \mathrm{C} 5 \mathrm{a}$ is cleaved from the amino-terminus of the alpha chain of the much larger C5 protein. Human C5a has an $N$-linked glycosylation site at Asn 64 that is not essential for biological activity, although it may regulate $\mathrm{C} 5 \mathrm{a}$ activity in vivo. ${ }^{12}$ The biological activity of C5a is greatly reduced by removal of the carboxyl-terminal residue (Arg) by carboxypeptidases, which is then known as C5a des Arg. Plasma C5a and C5a des Arg are quickly cleared from the circulation by the liver, secretion in renal glomeruli, and by binding to $\mathrm{C} 5$ a receptors and subsequent internalization. $^{13}$

$\mathrm{C} 5 \mathrm{a}$ is a potent anaphylatoxin that at low nanomolar concentrations acts as a chemoattractant for myeloid cells including neutrophils (polymorphonuclear neutrophils [PMNs]), monocytes, macrophages, basophils, and eosinophils. At higher concentrations, C5a can elicit superoxide generation and enzyme release responses, especially in PMNs. ${ }^{14}$ In addition, C5a can induce smooth muscle contraction, vasodilation, and apoptosis. C5a des Arg has many of the same functions, although higher concentrations are needed to elicit biological responses. In some instances, C5a des Arg may differ from $\mathrm{C} 5 \mathrm{a}$ in its activity. For example, in the presence of interleukin (IL)-3, C5a induces generation of leukotriene C4, IL-4, and IL-13 from human basophils. In contrast, C5a des Arg induces IL-4 and IL-13 production but minimal

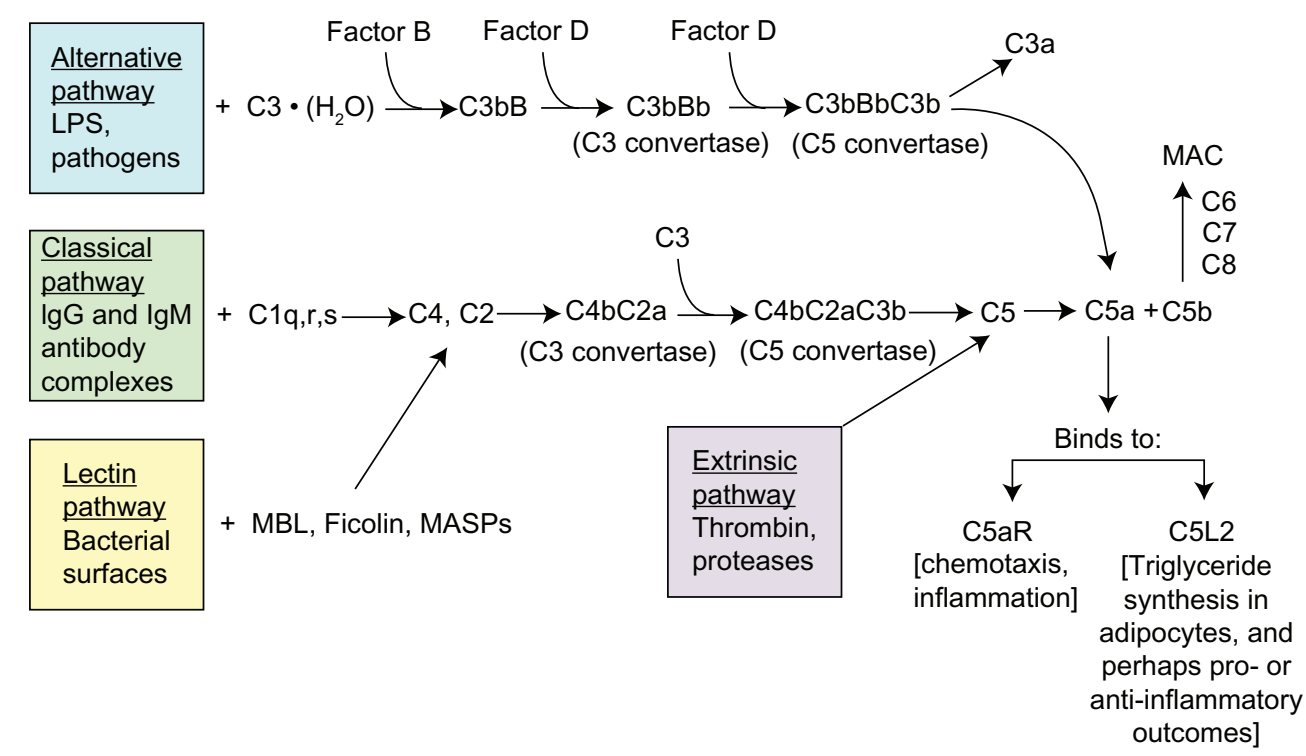

Figure I Complement activating pathways that lead to the formation of C5a.

Abbreviations: IgG, immunoglobulin G; IgM, immunoglobulin M; LPS, lipopolysaccharide; MAC, membrane attack complex; MASPs, mannose-binding lectin-associated serine proteases; MBL, mannose-binding lectin. 
leukotriene $\mathrm{C} 4$ release and may function as a super-agonist for IL-13 release from basophils. ${ }^{15}$

\section{C5a receptors}

C5aR belongs to the G protein-coupled receptor (GPCR) family, of which more than 800 members are expressed in humans with a multitude of functions regulating physiological, neurophysiological, and immune activities (Figure 2). ${ }^{16}$ As indicated previously, C5aR belongs to the rhodopsin family of seven transmembrane-containing GPCRs. Typically, following C5a binding to its cognate receptors, conformational changes in $\mathrm{C} 5 \mathrm{aR}$ occur, resulting in the activation of heterotrimeric guanine nucleotide-binding proteins (G proteins). $G$ proteins are composed of $\alpha, \beta$, and $\gamma$ subunits. Subsequently, guanosine diphosphate (GDP) (bound to the Go subunit) is exchanged for guanosine triphosphate (GTP) then the G $\beta$ and $\gamma$ subunits are dissociated from the G $\alpha$ subunit. This leads to signaling via molecules such as cyclic adenosine monophosphate and calcium mitogen-activated protein (MAP) kinases. Signaling is terminated by phosphorylation of the cytoplasmic tail of the GPCR by G protein-coupled receptor kinases (GRKs) followed by recruitment of $\beta$-arrestins to the cytoplasmic tail (Figure 2). Beta-arrestins block $\mathrm{G}$ protein binding and promote receptor "desensitization" followed by internalization via clathrin-coated pits. ${ }^{17} \mathrm{C} 5 \mathrm{aR}$ phosphorylation mainly occurs on serine residues at the carboxyl terminal, although protein kinase $\mathrm{C}$ ( $\mathrm{PKC}$ )-mediated phosphorylation sites (Arg-X-X-Ser-X-Arg-X) are found in the third cytoplasmic loop of C5aR (reviewed in Rabiet et $\mathrm{al}^{18}$ ). The GRKs GRK2 and GRK3 are involved in the phosphorylation of two serine pairs: either Ser332 and Ser334 or Ser334 and Ser338, which is necessary for subsequent phosphorylation of other serine residues and for receptor internalization. ${ }^{19}$
It is thought that GPCRs are not simple on and off switches, but, depending on the agonist and the resultant conformational changes, the $\mathrm{G}$ protein signaling pathway or the $\beta$-arrestin signaling pathway is preferentially activated. ${ }^{17}$ However, recent evidence suggests that signaling by GPCRs is much more complex due to the ability to bind both Gos (stimulating production of cAMP) and Goi (inhibiting cAMP production). There is also activation of the MAP kinase signaling pathway through $\beta$-arrestins, independent of $\mathrm{G}$ proteins. ${ }^{20} \mathrm{C} 5 \mathrm{aR}$ associates with two distinct $\mathrm{G} \alpha$ subunits: Goi, which is pertussis toxin (PTX) sensitive and Go15 (Go16 in humans), which is PTX insensitive. ${ }^{21,22}$ Beta-arrestins can simultaneously inhibit $\mathrm{G}$ protein-mediated signaling and transduce downstream signaling pathways. The multifunctional aspects of $\beta$-arrestins that include receptor internalization, trafficking, and signaling are achieved by protein conformational changes and post-translation modifications of $\beta$-arrestins. ${ }^{23}$

C5aR was cloned both by Boulay et $\mathrm{al}^{19}$ and Gerard and Gerard $^{24}$ in 1991. It has a mass of approximately $42 \mathrm{kDa}$ with 350 aa. C5aR is expressed in a wide variety of cells and tissues (reviewed in Monk et $\mathrm{al}^{12}$ ). Activation of C5aR results in the activation of several signaling pathways, including phosphatidylinositol 3-kinase (PI-3K)/protein kinase B (Akt), ${ }^{25}$ phospholipase $\mathrm{D},{ }^{26} \mathrm{PKC}$, and MAP kinase $^{27}$ pathways. $\mathrm{C} 5 \mathrm{a}$ in neutrophils can activate nuclear factor of kappa light polypeptide gene enhancer in B cells inhibitor, alpha $(\mathrm{I} \kappa \mathrm{B} \alpha)$ and inhibit nuclear factor kappa-

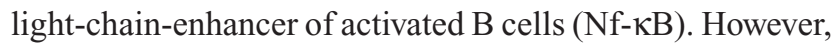
in macrophages, $\mathrm{C} 5 \mathrm{a}$ activates $\mathrm{Nf}-\kappa \mathrm{B} .{ }^{28} \mathrm{C} 5 \mathrm{a}$ generates sphingosine-1-phosphate (S1P) in macrophages, ${ }^{29}$ which is involved in several cellular processes, including the regulation of lymphocyte trafficking. ${ }^{30}$

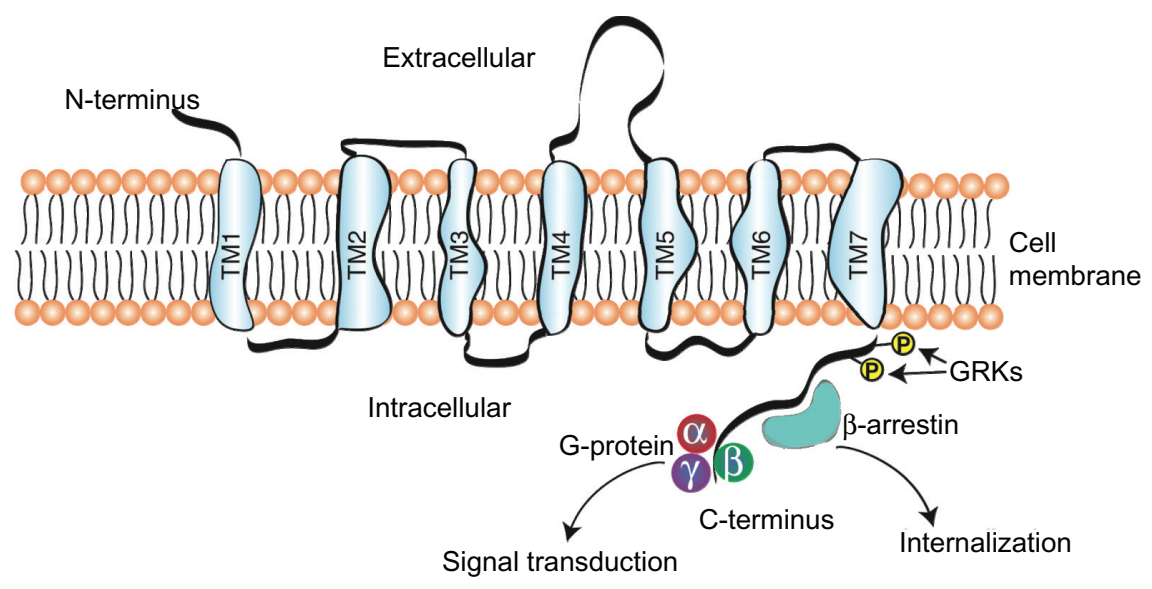

Figure 2 Diagram of a classical model of a seven transmembrane receptor with associated $G$ protein and $\beta$-arrestin molecules. Abbreviations: GRKs, G protein-coupled receptor kinases; TM, transmembrane region. 
The structure of C5aR consists of seven transmembrane regions (TM) connected by extracellular (EC) and intracellular (IC) loops in addition to the amino-terminal (N-terminal) extracellular and carboxyl terminal (C-terminal) intracellular tails or segments (Figures 2 and 3). One $N$-linked glycosylation site is found at Asn 5. Mutational analysis reveals that the first EC loop consists of residues in the Trp-XPhe-Gly (W-X-F-G) that cannot be substituted in the case of $\mathrm{C} 5 \mathrm{a}$-mediated activation, although substitution does not affect $\mathrm{C} 5$ a binding. ${ }^{31}$ The $\mathrm{W}-\mathrm{X}-\mathrm{F}-\mathrm{G}$ motif is found in many rhodopsin-like GPCRs. In contrast, the third EC loop can tolerate substitutions but appears to play less of a role in receptor activation. Further, the third IC loop followed by the second IC loop, the first IC loop, and the C-terminal tail contain the most number of residues that cannot be substituted to maintain $\mathrm{G}$ protein activation. ${ }^{32,33}$ Studies also suggest that $\mathrm{C} 5 \mathrm{aR}$ monomers can form oligomeric structures. ${ }^{33}$ Klco et al $^{33}$ demonstrated cross-linking of $\mathrm{C} 5$ a receptors in membranes prepared from human neutrophils as well as from membranes prepared from stably transfected Chinese hamster ovary cells. It is thought that TM1 and 2 and possibly TM4 are involved in this process. Further, Hüttenrauch et $\mathrm{al}^{34}$ also found that $\mathrm{C} 5 \mathrm{aR}$ can form hetero-oligomers with CCR5 (a receptor that facilitates human immunodeficiency virus entry into cells). In C5a-stimulated macrophages, C5aR and CCR5 co-internalize and involve GRKs and $\beta$-arrestins that can cross-phosphorylate and co-internalize unligated receptors, thus regulating heterologous receptors.

A second receptor for $\mathrm{C} 5 \mathrm{a}, \mathrm{C} 5 \mathrm{a}$ receptor-like 2 (C5L2), was cloned by Ohno et al, ${ }^{35}$ with a predicted molecular weight of $37 \mathrm{kDa}$. C5L2 is also a seven TM receptor that is uncoupled from $\mathrm{G}$ proteins because of lack of the Asp-ArgTyr (D-R-Y) motif, which in C5aR is Asp-Arg-Phe (D-R-F) and in C5L2 is Asp-Leu-Cys (D-L-C) (Figure 3). C5L2 lacks the Asn-Pro-X-X-Tyr (N-P-X-X-Y) motif, therefore is unable to couple to G proteins. ${ }^{36} \mathrm{C} 5 \mathrm{~L} 2$ (similarly to $\mathrm{C} 5 \mathrm{aR}$ ) contains acidic and tyrosine residues in the $\mathrm{N}$-terminal region that facilitate binding to $\mathrm{C} 5 \mathrm{a} .{ }^{12}$ No calcium mobilization occurs in C5a-stimulated C5L2-transfected cells. C5L2 contains an $N$-linked glycosylation site at Asn3. Similarities also exist between C5aR and C5L2 in the hydrophobic and charged residues in the TMs that interact with $\mathrm{C}$-terminus of C5a. However, the ability of the two receptors to bind C5a is quite different, since antibodies against the N-terminal region of $\mathrm{C} 5 \mathrm{~L} 2$ or mutations in the $\mathrm{N}$-terminal acidic and tyrosines interfere with the ability of C5L2 to bind C5a des Arg but with no effects on C5a binding. ${ }^{37}$ Weak intracellular mobilization is found when the Asp-Leu-Cys (D-L-C) motif is replaced with Asp-Arg-Cys (D-R-C) in C5L2 and co-expressed with G $\alpha 16$ in 293 cells. ${ }^{36}$ Further, IC3 lacks a conserved basic region Lys-Thr-Leu-Lys (K-T-L-K), which is present in $\mathrm{C} 5 \mathrm{aR}$, and activation of the MAP kinase

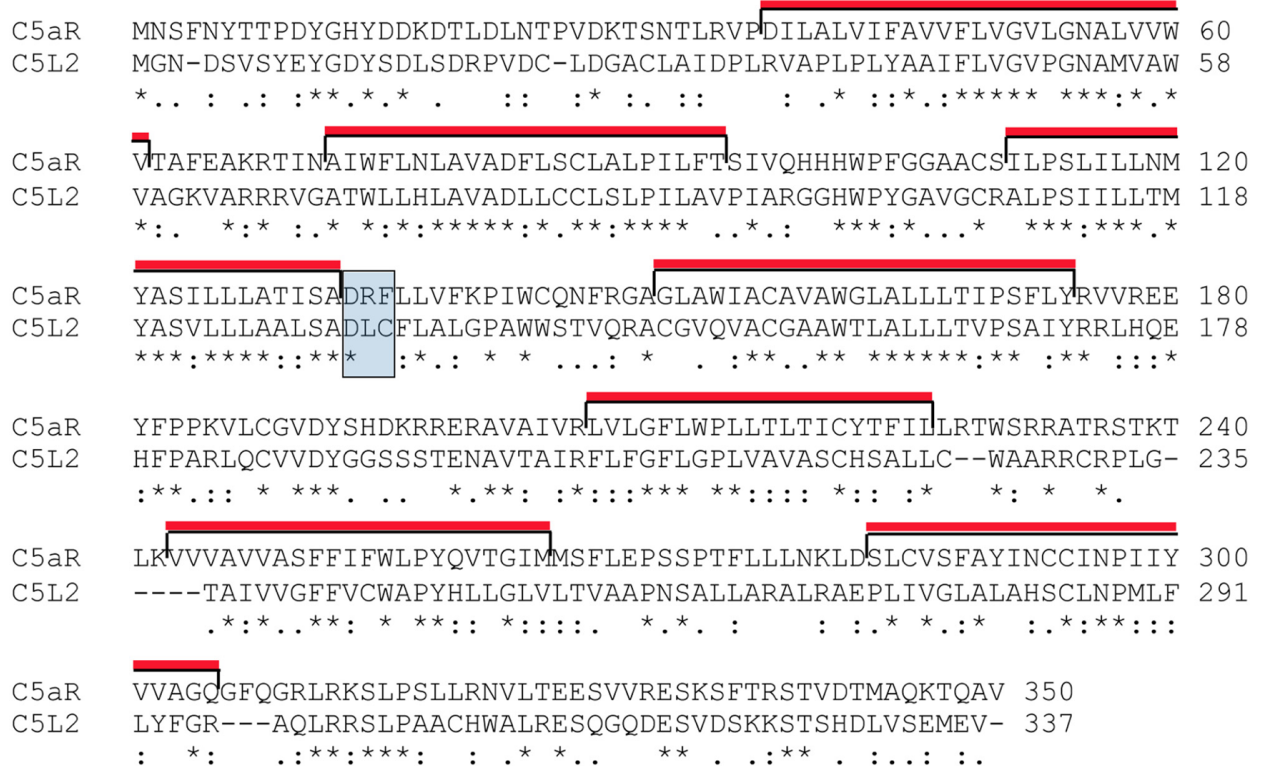

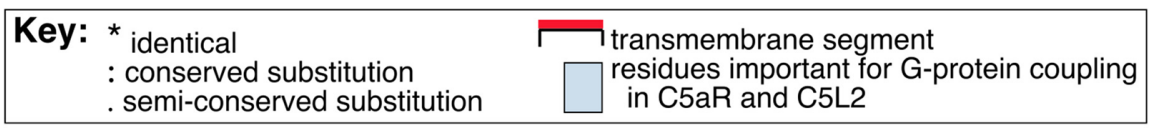

Figure 3 Amino acid sequence alignment of the human $C 5$ a receptors $C 5 a R$ and $C 5 L 2$. 
pathway does not occur in C5a-stimulated C5L2-transfected cells. ${ }^{36}$ C5L2 has been postulated to be a non-signaling receptor for $\mathrm{C} 3 \mathrm{a}$ and acylation-stimulating protein (ASP/ C3a des Arg), which is involved in lipid and carbohydrate metabolism. ${ }^{38}$ C5L2 can bind C5a but binds C5a des Arg with a higher affinity than $\mathrm{C} 5 \mathrm{aR} .{ }^{37}$ Whether C5L2 can bind C3a is controversial. ${ }^{12}$ There is a $35 \%$ sequence homology between C5aR and C5L2 (Figure 3). ${ }^{39}$

Expression of C5L2 is found in granulocytes and immature dendritic cells. Expression is also found in tissues such as that of the testis and spleen, with weaker expression in the kidney, lung, liver and heart. ${ }^{35}$ In a rat model of sepsis-induced by cecal ligation and puncture, our studies have found that C5L2 protein expression is increased in liver and lung, and blocking anti-C5L2 antibodies increased serum IL-6 levels. ${ }^{40}$ Macrophages and PMNs obtained form $\mathrm{C} 5 \mathrm{~L} 2^{-/-}$mice and when stimulated with $\mathrm{C} 5 \mathrm{a}$ they exhibited decreased phosphorylation of extracellular signal-regulated kinase (ERK) 1/2 in comparison with cells obtained from wild-type mice. ${ }^{41}$ The same group has also found that immune complex-induced lung injury was attenuated in $\mathrm{C} 5 \mathrm{~L} 2^{-/-}$mice, whereas another group described that $\mathrm{C} 5 \mathrm{~L} 2^{-/-}$mice exhibited intensified immune complex-induced lung injury. ${ }^{42}$ Further, in the genetic absence of either $\mathrm{C} 5 \mathrm{aR}$ or $\mathrm{C} 5 \mathrm{~L} 2$, or blockade of either $\mathrm{C} 5 \mathrm{aR}$ or $\mathrm{C} 5 \mathrm{~L} 2$, survival improved in mid-grade sepsis in which $60 \%-70 \%$ lethality occurs. In addition, buildup of pro-inflammatory mediators was attenuated. However, in high-grade sepsis (100\% lethality), combined blockade of C5aR and C5L2 was necessary for survival. C5L2 was necessary for release of high-mobility group box 1 protein (HMGB1) during sepsis. ${ }^{43}$ Studies by Zhang et $\mathrm{al}^{44}$ have suggested a critical role for $\mathrm{C} 5 \mathrm{~L} 2$ in the pathogenesis of asthma, since it was found that C5L2 was required for the development of ovalbumin (OVA) and house-dust mite-induced allergy and that C5L2 suppresses Th1 and Th17 differentiation. Chen et $\mathrm{al}^{41}$ also described reduced inflammatory cell buildup in the lung when experimental asthma was induced in C5L2 $2^{-/}$mice. The role that C5L2 plays in inflammatory responses is controversial and unresolved. Furthermore, it has been suggested that C5L2 functions as an intracellular receptor rather than as a receptor expressed on the cell surface. ${ }^{45}$ How C5a or C5a des Arg would obtain access to intracellular C5L2 is a matter of debate.

$\mathrm{C} 5 \mathrm{a}-\mathrm{C} 5 \mathrm{aR}$ interactions involve at least two sites on $\mathrm{C} 5 \mathrm{aR},{ }^{46}$ as opposed to other chemoattractants such as fMLP that involve only one site (the transmembrane domain) of their cognate GPCR. ${ }^{47}$ The disulfide-linked core region (1-63 aa) of C5a binds to the N-terminal segment, and the third extracellular loop of $\mathrm{C} 5 \mathrm{aR}$ and the $\mathrm{C}$-terminal of $\mathrm{C} 5 \mathrm{a}$ bind to the pocket formed by the fifth TM domain. Deletion mutation analysis suggests that both the $\mathrm{N}$ - and C-terminal residues are involved in receptor binding and activation. ${ }^{48}$ Our studies have suggested that there are several discontinuous regions of $\mathrm{C} 5 \mathrm{a}$ that interact with $\mathrm{C} 5 \mathrm{aR} .{ }^{10}$ Further, studies have shown that C-terminal synthetic peptides as short as eight aa are able to interact and induce C5aR-mediated function, albeit at much higher concentrations of the peptide than the intact C5a molecule. ${ }^{48}$

Recent studies suggest that different ligands or agonists for the same receptor can direct receptor signaling, resulting in different responses - this is referred to as "biased agonism." ${ }^{49}$ For example, seventeen kilodalton protein (Skp), present in the periplasm of Gram-negative bacteria as a $17 \mathrm{kDa}$ molecular chaperone, can bind and activate C5aR. Skp is a chemoattractant for neutrophils (PMNs) but is unable to induce superoxide generation from PMNs and granule enzyme release. In contrast, C5a can be a chemoattractant for PMNs and a secretagogue, eliciting PMN degranulation and superoxide generation responses. ${ }^{50}$ The inability of Skp to act as a secretagogue is due to the presence of Gln103 as the amino acid residue equivalent to Leu72 present in the C-terminal of C5a that interacts with the C5a receptor. If the Gln103 in Skp is substituted with Leu72, it confers to Skp the ability to function as a secretagogue. Thus, structural differences in the C5aR ligands due to their amino acid sequence can influence the type of response in C5aR-mediated functions in neutrophils. Further, studies suggest that ligands such as ribosomal protein S19 (RP S19) acquire the ability to bind $\mathrm{C} 5 \mathrm{aR}$ and modulate $\mathrm{C} 5 \mathrm{a}$-mediated responses in neutrophils and monocytes upon dimerization (reviewed in Yamamoto ${ }^{51}$ ). RP S19 is a ribosomal component that is released during apoptosis and is able to chemoattract monocytes, which then help in clearing the apoptotic cells that released the RP S19. However, RP S19 inhibits C5amediated neutrophil chemotaxis and promotes neutrophil apoptosis.

\section{Cross-talk between the complement system and Toll-like receptors (TLRs)}

The complement system appears to have evolved as an ancient defense strategy against microbial pathogens. It is now clear that the complement system plays an important role in maintaining homeostasis by orchestrating cross-talk with other receptors that recognize pathogen-associated molecular patterns, thus bridging innate and adaptive immunity. 
TLRs are essential components of the innate immune response system. They consist of transmembrane receptors that recognize pathogen-associated molecular pattern molecules such as LPS from Gram-negative bacteria. LPS is recognized by TLR4, while bacterial flagellin is recognized by TLR5, and so on. ${ }^{52}$ In addition, endogenous ligands for TLRs that include heat shock proteins and HMGB1 have also been reported. Activation of TLRs on the surface of phagocytes results in production of several pro-inflammatory and regulatory cytokines and chemokines such as IL-6, IL-12, IL-8, tumor necrosis factor-alpha (TNF $\alpha$ ), and IL-1 $\beta$. Both the complement system and TLRs are vital for mounting inflammatory responses. Recent findings suggest that the two systems can interact and modulate signal transduction pathways. For instance, Okusawa et $\mathrm{a}^{53}$ found that when human monocytes were exposed to both C5a and LPS, the levels of IL-1 $\beta$ induction were far greater than when the monocytes were stimulated with either agonist alone. These findings suggest a synergistic interaction between C5aR and TLR4 receptors. It is likely that in vivo, both systems are activated simultaneously upon recognition of a pathogen. In contrast, C5a suppressed IL-12 production from interferongamma (IFN $\gamma$ )-primed monocytes stimulated with LPS ${ }^{54}$ or in Staphylococcus aureus plus IFN $\gamma$-stimulated human monocytes but not in dendritic cells, even though dendritic cells express C5aR and TLR $4 .{ }^{55}$ This inhibition was partially prevented when monocytes were pretreated with the Goi inhibitor PTX. However, C5a failed to suppress TNF $\alpha$ and IL-10 production from monocytes stimulated with $S$. aureus. Further, Hawlisch et $\mathrm{al}^{56}$ found that C5a inhibited not only LPS and CD40-mediated IL-12 production in macrophages but also that of IL-23 and IL-27. This C5a-mediated modulation appeared to involve the signaling molecules PI-3K and ERK. These findings suggest that C5a can modulate the innate (TLR4) and adaptive (CD40) responses and thus help regulate responses to infection and autoimmunity mediated by the IL-12 family of cytokines. ${ }^{57}$ Other studies have found that while LPS-mediated IL-12 production is suppressed by C5a-C5aR interaction, C5a enhanced LPS-induced TNF $\alpha$, IL-1 $\beta$, and IL-6 production in mice. ${ }^{58}$ Our studies have suggested that LPS-mediated IL-17 and IL-23 production by macrophages was inhibited in the copresence of C5a. ${ }^{59}$ C5a-mediated inhibition required the presence of $\mathrm{C} 5 \mathrm{aR}$, as the macrophages obtained from $\mathrm{C}_{5} \mathrm{aR}^{-/}$mice exhibited little inhibition. Furthermore, the macrophages obtained from $\mathrm{C} \mathrm{aR}^{-/-}$mice exhibited enhanced production of IL-17 in the presence of LPS in comparison to macrophages from wildtype mice. $\mathrm{C} 5 \mathrm{a}-\mathrm{C} 5 \mathrm{aR}$ interaction resulted in the activation of MEK1/2, ERK1/2, and PI-3K/Akt pathways, resulting in IL-10 production that then potently inhibited IL-17A and IL-23 production, thus limiting inflammation. Interestingly, in the copresence of C5a, we also found that LPS-mediated IL-17F production is enhanced in macrophages and in vivo IL-17F production in endotoxemia in mice required the presence of $\mathrm{C} 5 \mathrm{a} .{ }^{60}$

In addition, Bachmaier et $\mathrm{al}^{61}$ found that in PMNs from sphingosine kinase 1 (SPHK1)-deficient mice, LPS failed to upregulate C5L2 expression. SPHK1 generates the signaling lipid S1P from ceramide that acts as a chemoattractant and a signaling molecule involved in diverse physiological processes such as cell growth and apoptosis. ${ }^{30}$ Exogenously administered S1P could have restored C5L2 expression, but it had no effect on $\mathrm{C} 5 \mathrm{aR}$ expression, suggesting that SPHK1 can regulate the expression of C5L2 in phagocytes via sphingosine interacting with its receptors that are also GPCRs. ${ }^{62}$ Recently, C5a was found to synergize with TLR2, which reacts with Porhyromonas gingivalis, resulting in increased TLR2-mediated cAMP production in macrophages. In turn, this inhibits nitric oxide-dependent killing of P. gingivalis. ${ }^{63}$

Interestingly, TLRs can also enhance C5a-mediated responses. ${ }^{64}$ Human peripheral blood monocytes stimulated with TLR ligands, such as LPS and zymosan, then subsequently stimulated with C5a showed enhanced expression of IL-8, suggesting that TLR activation can modulate $\mathrm{C} 5 \mathrm{aR}$-mediated responses. Further, this study found that TLR activation leads to the downregulation of $\mathrm{C} 5 \mathrm{aR}$ expression and reduces $\mathrm{C} 5 \mathrm{~L} 2$ activity (which can be measured indirectly by measuring HMGB1, as HMGB1 expression is dependent on the presence of $\mathrm{C} 5 \mathrm{~L} 2$ and not $\mathrm{C} 5 \mathrm{aR}) .{ }^{64}$

\section{Cross-talk with other receptors}

$\mathrm{Fc}$ receptors (FcRs) that bind to the $\mathrm{Fc}$ portion of $\operatorname{IgG}$ are known as FcyRs and are involved in phagocytosis, release of inflammatory mediators, and antibody-mediated autoimmunity. ${ }^{21}$ There are several classes of Fc $\gamma R s$ : Fc $\gamma$ RI (isoforms Fc $\gamma$ RIA, IB, and IC), Fc $\gamma$ RII (isoforms FcyRIIA,

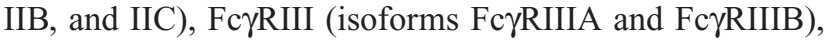
and Fc $\gamma$ RIV. ${ }^{65,66}$ Due to the presence of the immunoreceptor tyrosine activation motif, Fc $\gamma R I, F c \gamma R I I I$, and Fc $\gamma R I V$ in mice (Fc $\gamma R$ I, IIa, IIC, and IIIA in humans) are considered to be activating receptors, while Fc $\gamma$ RIIB in mice and Fc $\gamma$ RIIB in humans are inhibitory receptors because of the presence of immunoreceptor tyrosine-based inhibitory motif. Studies indicate that $\mathrm{C} 5 \mathrm{a}$ can upregulate the activating Fc $\gamma \mathrm{RII}$ and downregulate the inhibitory Fc $\gamma \mathrm{RII}$ expression in mouse 
alveolar macrophages, ${ }^{67}$ thus playing a crucial role in autoimmunity by modulating FcRs. Studies also suggest that C5aR may mediate cross-talk between the complement and coagulation pathways. Anti-phospholipid antibody can induce complement activation and consequent $\mathrm{C} 5 \mathrm{a}$ production. Interaction of $\mathrm{C} 5 \mathrm{a}$ with $\mathrm{C} 5 \mathrm{aR}$ leads to enhancement of tissue factor (TF) on PMNs. ${ }^{68} \mathrm{TF}$ is a transmembrane glycoprotein that enables cells to initiate the coagulation pathway by binding to factor VII. ${ }^{68}$ When PMNs were incubated with a selective $\mathrm{C} 5 \mathrm{aR}$ antagonist (AcF-[OPdChaWR]), C5ainduced TF expression enhancement was abrogated, further confirming that $\mathrm{C} 5 \mathrm{a}-\mathrm{C} 5 \mathrm{aR}$ interaction is necessary for enhanced TF expression on PMNs.

\section{Therapeutic strategies}

The complement system has been linked to several diseases such as Alzheimer's, dementia, ischemia-reperfusion injury, acute lung injury, asthma sepsis, rheumatoid arthritis (RA), atherosclerosis, glomerulonephritis, and multiple sclerosis. ${ }^{5}$ Modulation of the $\mathrm{C} 5 \mathrm{a}-\mathrm{C} 5 \mathrm{aR}$ interaction is crucial for elimination of pathogens and equally important in maintaining homeostasis and preventing the pathophysiology of the disease process. $\mathrm{C} 5 \mathrm{a}-\mathrm{C} 5 \mathrm{aR}$ signaling is also involved in the interaction of antigen-presenting cells and $\mathrm{T}$ cells. Locally produced C5a interacts with C5aR (expressed by both antigen-presenting cells and T cells) and modulates $\mathrm{T}$ cell differentiation, survival, and proliferation. ${ }^{69,70}$ Excessive C5a production has been implicated in the pathophysiology of sepsis, in which the immune paralysis of neutrophil function, disseminated coagulation, and lymphocyte apoptosis occurs, leading to tissue damage and multiorgan failure. ${ }^{5}$ Increasingly, $\mathrm{C} 5 \mathrm{a}$ has been implicated in cancer by promoting angiogenesis, production of growth factors, proliferation, prevention of apoptosis, suppression of antitumor immunity, and invasion and migration (reviewed in Rutkowski et $\mathrm{al}^{71}$ ).

Several approaches for inhibiting C5a-C5aR signaling have been developed; but, given our incomplete and conflicting understanding of C5L2 signaling and functions, C5a-C5L2 signaling has not been targeted. The main effort has been concentrated on $\mathrm{C} 5 \mathrm{aR}$ through the use of anti-C5aR antibodies, peptides, and small molecules that inhibit C5aR functions. ${ }^{12}$ These include hexapeptides derived from the $\mathrm{C}$-terminus of $\mathrm{C} 5 \mathrm{a}$ that have a cyclic conformation, such as AcF-[OPdChaWR] (termed PMX53 or 3D53). ${ }^{12,72}$

However, inhibition of $\mathrm{C} 5 \mathrm{aR}$ signaling requires considerable caution. Recently, studies have suggested a protective role of $\mathrm{C} 5 \mathrm{aR}$ in asthma. ${ }^{73}$ While $\mathrm{C} 5 \mathrm{aR}$ inhibition may be beneficial in certain inflammatory conditions, it may trigger inflammatory responses to allergens in the lungs. ${ }^{12}$ Further, in the initial stages of Alzheimer's disease, signaling via C5aR may be helpful in clearing damaged neurons, but, in the later stages of the disease, it may be detrimental, making the timing of therapeutic interventions problematic. In a mouse model of Alzheimer's, administration of a C5aR antagonist appeared to reduce amyloid deposits and improve cognition. ${ }^{74}$ In addition, when PC12 cells (a pheochromocytoma-derived cell line that can be induced to form a neuronal phenotype in the presence of nerve growth factor) are exposed to C5a, the growth of the neuronal cells is inhibited due to a direct C5amediated inhibitory effect on mitochondrial respiration and cytochrome c oxidase activity. ${ }^{75}$ These studies suggest that C5a may play a role in neuronal cell growth inhibition linked to the neuro-degeneration that occurs during the normal aging process and under pathophysiological conditions.

Although several potential therapeutics have been developed against several complement proteins (reviewed in Ricklin and Lambris ${ }^{76}$ ), very few exist that target the $\mathrm{C} 5 \mathrm{a}-\mathrm{C} 5 \mathrm{aR}$ interaction are on the market or in clinical trials. Eculizumab (Soliris) developed by Alexion Pharmaceuticals (Cheshire, CT) is a humanized antibody that binds to C5 and prevents the formation of $\mathrm{C} 5 \mathrm{a}$ and $\mathrm{C} 5 \mathrm{~b}$ as well as the subsequent formation of the membrane attack complex $\mathrm{C} 5 \mathrm{~b}-9$. This monoclonal antibody has been approved for the treatment of paroxysmal nocturnal hemoglobinuria, a disease in which red blood cell lysis occurs frequently accompanied with severe anemia and venous thrombosis. Eculizumab administration has resulted in increased hemoglobin levels and a reduction in the need for red blood cell transfusion. ${ }^{39}$ The drug is in preclinical trials for several diseases and is being tested for use in transplant rejection, autoimmune diseases, asthma, age-related macular degeneration, and myocardial infarction. There is also a $25 \mathrm{kDa}$ single-chain version of eculizumab (known as pexelizumab) that lacks the constant region of the eculizumab antibody and is short acting; it has been used in clinical trials of cardiovascular diseases. Mubodina ${ }^{\circledR}$ (Adienne Pharma and Biotech, Bergamo, Italy) is another antibody that prevents $\mathrm{C} 5$ cleavage to $\mathrm{C} 5 \mathrm{a}$ and $\mathrm{C} 5 \mathrm{~b}$, but it recognizes a different epitope from that recognized by eculizumab. This antibody is being developed for the treatment of patients with atypical hemolytic uremic syndrome that adversely affects glomerular function. Neutrazumab (G2 therapies, Darlinghurst, NSW, Australia), a blocking anti-C5aR antibody, is in preclinical development for RA and stroke. JPE 1375 and JSM 7717, developed by Jerini Ophthalmic Inc (New York, NY), are C5aR small- 
molecule peptide mimetic antagonists that are in clinical trials for renal and ocular diseases. PMX-53 (Teva Pharmaceutical Industries Ltd, Petah Tikva, Israel) has completed clinical Phase II trials for RA and psoriasis, with limited success. ${ }^{39}$ PMX-53 has a short half-life and is rapidly broken down in the intestinal mucosa, which may limit its therapeutic usage. . $778^{7,78}$

ARC 1905 (Archemix Corp, Cambridge, MA), an aptamer inhibitor of C5, is in clinical stages for age-related macular degeneration. Aptamers are single nucleotide sequences directed against target proteins and can be easily derivatized for clinical optimization. ARC 1905 is an anti-C5 RNA sequence that binds to $\mathrm{C} 5$ and inhibits its cleavage to $\mathrm{C} 5 \mathrm{a}$ and C5b. To improve its pharmacokinetics, a $40 \mathrm{kDa}$ polyethylene glycol (PEG) group has been added to the $5^{\prime}$ end. Another drug, TNX 558 (Tanox, Houston, TX), which is a humanized anti-C5a antibody, is in development and in preclinical stages. Other humanized antibodies to C5a are being developed by InflaRx GmbH (Jena, Germany) for treatment of sepsis. One drawback of small-molecule therapeutics is their off-target effects. For example, PMX-53 affects the activity of Masrelated gene 2 and tachykinin NK2 receptor. ${ }^{79,80}$ Bioavailability and half-life are other considerations.

$S$. aureus strains secrete a 121 residue protein, chemotaxisinhibiting protein of $S$. aureus (CHIPS), which can bind to $\mathrm{C} 5 \mathrm{aR}$ as well as formylated peptide receptor and prevents PMN and monocyte chemotaxis against $\mathrm{C} 5 \mathrm{a} .{ }^{81} \mathrm{CHIPS}$ blocks $\mathrm{C} 5 \mathrm{aR}$ activation by binding to the $\mathrm{N}$-terminus of the $\mathrm{C} 5 \mathrm{aR}$ receptor. Peptide mimics of CHIPS are being developed that imitate the blocking effect of CHIPS on C5a-C5aR interaction but lack its immunogenic properties. ${ }^{82} \mathrm{C} 5 \mathrm{a}$ and CHIPS do not share homology in either sequence or tertiary structure but have similar size and shape, thus are able to compete for the same receptor.

To date, anti-C5L2 antibodies have been developed that block C5a-C5L2 interaction, ${ }^{45}$ but these antibodies have mainly been used to gain insights into C5L2-modulated signal transduction and functions. The small molecule A8D71-73 is the only known antagonist that blocks C5a and C5a des Arg binding to both C5aR and C5L2. ${ }^{83}$

\section{Conclusion}

Complement activation ultimately leads to the formation of $\mathrm{C} 5 \mathrm{a}$ and its interaction with its two receptors, C5aR and C5L2, activating signaling pathways that are important in defending against pathogens and maintaining homeostasis. Targeting C5aR and/or C5L2 in a manner that prevents interaction with $\mathrm{C} 5 \mathrm{a}$ when produced in excessive amounts may ameliorate many disease manifestations. However, studies that can help further understand C5a-C5aR/C5L2 interactions may prove beneficial in designing new therapeutic strategies without compromising the ability of the patient to rid themselves of noxious pathogenic insults.

\section{Acknowledgments}

This work was supported by NIH grants GM-61656 and GM-29507 (PAW).

\section{Disclosure}

The authors report no conflicts of interest in this work.

\section{References}

1. Sahu A, Lambris JD. Structure and biology of complement protein C3, a connecting link between innate and acquired immunity. Immunol Rev. 2001;180:35-48.

2. Klos A, Tenner AJ, Johswich KO, Ager RR, Reis ES, Köhl J. The role of the anaphylatoxins in health and disease. Mol Immunol. 2009;46(14): 2753-2766.

3. Niculescu F, Rus H. The role of complement activation in atherosclerosis. Immunol Res. 2004;30(1):73-80.

4. Welch TR. Complement in glomerulonephritis. Nat Genet. 2002;31(4): 333-334.

5. Rittirsch D, Flierl MA, Ward PA. Harmful molecular mechanisms in sepsis. Nat Rev Immunol. 2008;8(10):776-787.

6. Sarma JV, Ward PA. The complement system. Cell Tissue Res. 2011;343(1):227-235.

7. Huber-Lang M, Sarma JV, Zetoune FS, et al. Generation of C5a in the absence of C3: a new complement activation pathway. Nat Med.2006; 12(6):682-687.

8. Ward PA, Zvaifler NJ. Quantitative phagocytosis by neutrophils. I. A new method with immune complexes. J Immunol. 1973;111(6): 1771-1776.

9. Huber-Lang M, Younkin EM, Sarma JV, et al. Generation of C5a by phagocytic cells. Am J Pathol. 2002;161(5):1849-1859.

10. Huber-Lang MS, Sarma JV, McGuire SR, et al. Structure-function relationships of human C5a and C5aR. J Immunol. 15, 2003;170(12): 6115-6124.

11. Sandoval A, Ai R, Ostresh JM, Ogata RT. Distal recognition site for classical pathway convertase located in the $\mathrm{C} 345 \mathrm{C} /$ netrin module of complement component C5. J Immunol. 2000;165(2):1066-1073.

12. Monk PN, Scola AM, Madala P, Fairlie DP. Function, structure and therapeutic potential of complement C5a receptors. Br J Pharmacol. 2007;152(4):429-448.

13. Manthey HD, WoodruffTM, Taylor SM, Monk PN. Complement component 5a (C5a). Int J Biochem Cell Biol. 2009;41(11):2114-2117.

14. Gerard C, Gerard NP. C5A anaphylatoxin and its seven transmembranesegment receptor. Annu Rev Immunol. 1994;12:775-808.

15. Eglite S, Plüss K, Dahinden CA. Requirements for C5a receptormediated IL-4 and IL-13 production and leukotriene $\mathrm{C} 4$ generation in human basophils. J Immunol. 2000;165(4):2183-2189.

16. Sprang SR, Elk JC. Cell signaling. Structural origins of receptor bias. Science. 2012;335(6072):1055-1056.

17. Rajagopal S, Rajagopal K, Lefkowitz RJ. Teaching old receptors new tricks: biasing seven-transmembrane receptors. Nat Rev Drug Discov. 2010;9(5):373-386.

18. Rabiet MJ, Huet E, Boulay F. The N-formyl peptide receptors and the anaphylatoxin C5a receptors: an overview. Biochimie. 2007;89(9): 1089-1106.

19. Boulay F, Mery L, Tardif M, Brouchon L, Vignais P. Expression cloning of a receptor for C5a anaphylatoxin on differentiated HL-60 cells. Biochemistry. 1991;30(12):2993-2999. 
20. Rosenbaum DM, Rasmussen SG, Kobilka BK. The structure and function of G-protein-coupled receptors. Nature. 2009;459(7245):356-363.

21. Schmidt RE, Gessner JE. Fc receptors and their interaction with complement in autoimmunity. Immunol Lett. 2005;100(1): 56-67.

22. Davignon I, Catalina MD, Smith D, et al. Normal hematopoiesis and inflammatory responses despite discrete signaling defects in Galpha15 knockout mice. Mol Cell Biol. 2000;20(3):797-804.

23. Shenoy SK, Lefkowitz RJ. $\beta$-arrestin-mediated receptor trafficking and signal transduction. Trends Pharmacol Sci. 2011;32(9):521-533.

24. Gerard NP, Gerard C. The chemotactic receptor for human C5a anaphylatoxin. Nature. 1991;349(6310):614-617.

25. Wrann CD, Tabriz NA, Barkhausen T, et al. The phosphatidylinositol 3-kinase signaling pathway exerts protective effects during sepsis by controlling C5a-mediated activation of innate immune functions. J Immunol. 2007;178(9):5940-5948.

26. Mullmann TJ, Siegel MI, Egan RW, Billah MM. Complement C5a activation of phospholipase D in human neutrophils. A major route to the production of phosphatidates and diglycerides. J Immunol. 1990;144(5): 1901-1908.

27. la Sala A, Gadina M, Kelsall BL. G(i)-protein-dependent inhibition of IL-12 production is mediated by activation of the phosphatidylinositol 3-kinase-protein 3 kinase B/Akt pathway and JNK. J Immunol. 2005; 175(5):2994-2999.

28. Guo RF, Riedemann NC, Ward PA. Role of C5a-C5aR interaction in sepsis. Shock. 2004;21(1):1-7.

29. Melendez AJ, Ibrahim FB. Antisense knockdown of sphingosine kinase 1 in human macrophages inhibits C5a receptor-dependent signal transduction, $\mathrm{Ca} 2+$ signals, enzyme release, cytokine production, and chemotaxis. J Immunol. 2004;173(3):1596-1603.

30. Maceyka M, Harikumar KB, Milstien S, Spiegel S. Sphingosine-1phosphate signaling and its role in disease. Trends Cell Biol. 2012;22(1): $50-60$.

31. Klco JM, Nikiforovich GV, Baranski TJ. Genetic analysis of the first and third extracellular loops of the C5a receptor reveals an essential WXFG motif in the first loop. J Biol Chem. 2006;281(17):12010-12019.

32. Matsumoto ML, Narzinski K, Kiser PD, Nikiforovich GV, Baranski TJ. A comprehensive structure-function map of the intracellular surface of the human C5a receptor. I. Identification of critical residues. $J$ Biol Chem. 2007;282(5):3105-3121.

33. Klco JM, Lassere TB, Baranski TJ. C5a receptor oligomerization. I. Disulfide trapping reveals oligomers and potential contact surfaces in a G protein-coupled receptor. J Biol Chem. 2003;278(37): 35345-35353.

34. Hüttenrauch F, Pollok-Kopp B, Oppermann M. G protein-coupled receptor kinases promote phosphorylation and beta-arrestin-mediated internalization of CCR5 homo- and hetero-oligomers. $J$ Biol Chem. 2005;280(45):37503-37515.

35. Ohno M, Hirata T, Enomoto M, Araki T, Ishimaru H, Takahashi TA. A putative chemoattractant receptor, $\mathrm{C} 5 \mathrm{~L} 2$, is expressed in granulocyte and immature dendritic cells, but not in mature dendritic cells. Mol Immunol. 2000;37(8):407-412.

36. Okinaga S, Slattery D, Humbles A, et al. C5L2, a nonsignaling C5A binding protein. Biochemistry. 2003;42(31):9406-9415.

37. Scola AM, Higginbottom A, Partridge LJ, et al. The role of the $\mathrm{N}$-terminal domain of the complement fragment receptor C5L2 in ligand binding. J Biol Chem. 2007;282(6):3664-3671.

38. Paglialunga S, Schrauwen P, Roy C, et al. Reduced adipose tissue triglyceride synthesis and increased muscle fatty acid oxidation in C5L2 knockout mice. J Endocrinol. 2007;194(2):293-304.

39. Woodruff TM, Nandakumar KS, Tedesco F. Inhibiting the C5-C5a receptor axis. Mol Immunol. 2011;48(14):1631-1642.

40. Gao H, Neff TA, Guo RF, et al. Evidence for a functional role of the second C5a receptor C5L2. FASEB J. 2005;19(8):1003-1005.

41. Chen NJ, Mirtsos C, Suh D, et al. C5L2 is critical for the biological activities of the anaphylatoxins C5a and C3a. Nature. 2007;446(7132): 203-207.
42. Gerard NP, Lu B, Liu P, et al. An anti-inflammatory function for the complement anaphylatoxin C5a-binding protein, C5L2. J Biol Chem. 2005;280(48):39677-39680.

43. Rittirsch D, Flierl MA, Nadeau BA, et al. Functional roles for C5a receptors in sepsis. Nat Med. 2008;14(5):551-557.

44. Zhang X, Schmudde I, Laumonnier Y, et al. A critical role for C5L2 in the pathogenesis of experimental allergic asthma. J Immunol. 2010; 185(11):6741-6752.

45. Bamberg CE, Mackay CR, Lee H, et al. The C5a receptor (C5aR) C5L2 is a modulator of C5aR-mediated signal transduction. J Biol Chem. 2010;285(10):7633-7644.

46. Siciliano SJ, Rollins TE, DeMartino J, et al. Two-site binding of C5a by its receptor: an alternative binding paradigm for $\mathrm{G}$ protein-coupled receptors. Proc Natl Acad Sci U S A. 1994;91(4):1214-1218.

47. Bestebroer J, de Haas CJ, van Strijp JA. How microorganisms avoid phagocyte attraction. FEMS Microbiol Rev. 2009. Epub Dec 11.

48. Hennecke M, Otto A, Baensch M, et al. A detailed analysis of the C5a anaphylatoxin effector domain: selection of $\mathrm{C} 5 \mathrm{a}$ phage libraries on differentiated U937 cells. Eur J Biochem. 1998;252(1):36-44.

49. Ye RD. Editorial: Biased agonism in chemoattractant receptor signaling. J Leukoc Biol. 2010;87(6):959-961.

50. Jia N, Semba U, Nishiura H, et al. Pivotal Advance: Interconversion between pure chemotactic ligands and chemoattractant/secretagogue ligands of neutrophil C5a receptor by a single amino acid substitution. J Leukoc Biol. 2010;87(6):965-975.

51. Yamamoto T. Roles of the ribosomal protein S19 dimer and the C5a receptor in pathophysiological functions of phagocytic leukocytes. Pathol Int. 2007;57(1):1-11.

52. Rakoff-Nahoum S, Medzhitov R. Toll-like receptors and cancer. Nat Rev Cancer. 2009;9(1):57-63.

53. Okusawa S, Dinarello CA, Yancey KB, et al. C5a induction of human interleukin 1. Synergistic effect with endotoxin or interferon-gamma. J Immunol. 1987;139(8):2635-2640.

54. Wittmann M, Zwirner J, Larsson VA, et al. C5a suppresses the production of IL-12 by IFN-gamma-primed and lipopolysaccharidechallenged human monocytes. J Immunol. 1999;162(11): 6763-6769.

55. Braun MC, Lahey E, Kelsall BL. Selective suppression of IL-12 production by chemoattractants. J Immunol. 2000;164(6):3009-3017.

56. Hawlisch H, Belkaid Y, Baelder R, Hildeman D, Gerard C, Köhl J. C5a negatively regulates toll-like receptor 4-induced immune responses. Immunity. 2005;22(4):415-426.

57. Diveu C, McGeachy MJ, Cua DJ. Cytokines that regulate autoimmunity. Curr Opin Immunol. 2008;20(6):663-668.

58. Zhang X, Kimura Y, Fang C, et al. Regulation of Toll-like receptormediated inflammatory response by complement in vivo. Blood. 2007;110(1):228-236.

59. Bosmann M, Sarma JV, Atefi G, Zetoune FS, Ward PA. Evidence for anti-inflammatory effects of C5a on the innate IL-17A/IL-23 axis. FASEB J. 2012;26(4):1640-1651.

60. Bosmann M, Patel VR, Russkamp NF, et al. MyD88-dependent production of IL-17F is modulated by the anaphylatoxin C5a via the Akt signaling pathway. FASEB J. 2011;25(12):4222-4232.

61. Bachmaier K, Guzman E, Kawamura T, Gao X, Malik AB. Sphingosine kinase 1 mediation of expression of the anaphylatoxin receptor C5L2 dampens the inflammatory response to endotoxin. PLoS One. 2012;7(2): e30742.

62. Rosen H, Gonzalez-Cabrera PJ, Sanna MG, Brown S. Sphingosine 1-phosphate receptor signaling. Annu Rev Biochem. 2009;78: 743-768.

63. Wang M, Krauss JL, Domon H, et al. Microbial hijacking of complementtoll-like receptor crosstalk. Sci Signal. 2010;3(109):ra11.

64. Raby AC, Holst B, Davies J, et al. TLR activation enhances C5a-induced pro-inflammatory responses by negatively modulating the second $\mathrm{C} 5 \mathrm{a}$ receptor, C5L2. Eur J Immunol. 2011;41(9):2741-2752.

65. Nimmerjahn F, Ravetch JV. Fcgamma receptors as regulators of immune responses. Nat Rev Immunol. 2008;8(1):34-47. 
66. Marques RB, Thabet MM, White SJ, et al. Genetic variation of the Fc gamma receptor $3 \mathrm{~B}$ gene and association with rheumatoid arthritis. PLoS One. 2010;5(10):e13173.

67. Shushakova N, Skokowa J, Schulman J, et al. C5a anaphylatoxin is a major regulator of activating versus inhibitory FcgammaRs in immune complex-induced lung disease. J Clin Invest. 2002;110(12): 1823-1830.

68. Ritis K, Doumas M, Mastellos D, et al. A novel C5a receptor-tissue factor cross-talk in neutrophils links innate immunity to coagulation pathways. J Immunol. 2006;177(7):4794-4802.

69. Lalli PN, Strainic MG, Yang M, Lin F, Medof ME, Heeger PS. Locally produced C5a binds to T cell-expressed C5aR to enhance effector T-cell expansion by limiting antigen-induced apoptosis. Blood. 2008;112(5): 1759-1766.

70. Strainic MG, Liu J, Huang D, et al. Locally produced complement fragments $\mathrm{C} 5 \mathrm{a}$ and $\mathrm{C} 3$ a provide both costimulatory and survival signals to naive CD4+ T cells. Immunity. 2008;28(3):425-435.

71. Rutkowski MJ, Sughrue ME, Kane AJ, Mills SA, Parsa AT. Cancer and the complement cascade. Mol Cancer Res. 2010;8(11):1453-1465.

72. Strachan AJ, Woodruff TM, Haaima G, Fairlie DP, Taylor SM. A new small molecule $\mathrm{C} 5 \mathrm{a}$ receptor antagonist inhibits the reverse-passive Arthus reaction and endotoxic shock in rats. J Immunol. 2000;164(12): 6560-6565.

73. Kohl J, Wills-Karp M. A dual role for complement in allergic asthma. Curr Opin Pharmacol. 2007;7(3):283-289.

74. Fonseca MI, Ager RR, Chu SH, et al. Treatment with a C5aR antagonist decreases pathology and enhances behavioral performance in murine models of Alzheimer's disease. J Immunol. 2009;183(2):1375-1383.
75. Martinus RD, Cook CJ. The effect of complement C5a on mitochondrial functions of PC12 cells. Neuroreport. 2011;22(12):581-585.

76. Ricklin D, Lambris JD. Complement-targeted therapeutics. Nat Biotechnol. 2007;25(11):1265-1275.

77. Woodruff TM, Pollitt S, Proctor LM, et al. Increased potency of a novel complement factor 5 a receptor antagonist in a rat model of inflammatory bowel disease. J Pharmacol Exp Ther. 2005;314(2):811-817.

78. Morgan M, Bulmer AC, Woodruff TM, et al. Pharmacokinetics of a C5a receptor antagonist in the rat after different sites of enteral administration. Eur J Pharm Sci. 2008;33(4-5):390-398.

79. Subramanian H, Kashem SW, Collington SJ, Qu H, Lambris JD, Ali H. PMX-53 as a dual CD88 antagonist and an agonist for Mas-related gene 2 (MrgX2) in human mast cells. Mol Pharmacol. 2011;79(6): 1005-1013.

80. Schnatbaum K, Locardi E, Scharn D, et al. Peptidomimetic C5a receptor antagonists with hydrophobic substitutions at the C-terminus: increased receptor specificity and in vivo activity. Bioorg Med Chem Lett. 2006;16(19):5088-5092.

81. Postma B, Poppelier MJ, van Galen JC, et al. Chemotaxis inhibitory protein of Staphylococcus aureus binds specifically to the C5a and formylated peptide receptor. J Immunol. 2004;172(11):6994-7001.

82. Bunschoten A, Ippel JH, Kruijtzer JA, et al. A peptide mimic of the chemotaxis inhibitory protein of Staphylococcus aureus: towards the development of novel anti-inflammatory compounds. Amino Acids. 2011;40(2):731-740.

83. Otto M, Hawlisch H, Monk PN, et al. C5a mutants are potent antagonists of the $\mathrm{C} 5 \mathrm{a}$ receptor $(\mathrm{CD} 88)$ and of $\mathrm{C} 5 \mathrm{~L} 2$ : position 69 is the locus that determines agonism or antagonism. $J$ Biol Chem. 2004;279(1): 142-151.
Cell Health and Cytoskeleton

\section{Publish your work in this journal}

Cell Health and Cytoskeleton is an international, peer-reviewed open access journal focusing on all aspects of cell structure and function contributing to normal physiology and cell health and exploring the pathogenesis of cell dysfunction leading to adverse conditions and disease in the organism. The journal welcomes papers covering original research,

\section{Dovepress}

basic science, reviews and evaluations, guidelines, expert opinion and commentary, case reports and extended reports. The manuscript management system is completely online and includes a very quick and fair peerreview system, which is all easy to use. Visit http://www.dovepress.com/ testimonials.php to read real quotes from published authors. 